REGULAR ARTICLE

\title{
STUDY OF MACROALGAE BIODIVERSITY IN THE WESTERN ALGERIAN COAST, TÉNÈS
}

\author{
TRAICHE ABDERRAOUF ${ }^{1}$, BELHAOUARI BENKHEDDA ${ }^{*}$, ROUEN-HACEN OMAR3 \\ ${ }^{1}$ Département Eau, Environnement et Development Durable, University of Chlef-Hassiba Benbouali, Algéria \\ ${ }^{2}$ Laboratoire Réseau de Surveillance Environnementale (LRSE), University of Oran 1 Ahmed Ben Bella, Algeria
}

\begin{abstract}
During this study we evaluated the spatio-temporal distribution of macroalgae in the western Algerian coast. This work was carried out in the intertidal zone near the municipality of Ténès. We carried out a seasonal sampling from July 2016 to April 2017, at four different sites. Nine species were identified. The highest species richness was observed in summer and early autumn. The most abundant algae observed were Ulva et Cystoseira. Ulva alga achieved the highest recovery rate 60,33\% in Spring. Laurencia obtusa and Spongomorpha arcta were the least abundant. Algae of economic interest have been observed in the coast of Tenes.
\end{abstract}

Keywords: Algae, Ulva, Cystoseira, Algerian Coast Ténès

\section{INTRODUCTION}

Macroalgae are species that are of great ecological and economic interest. The depth reached by certain species in the marine environment can reach a few meters. Intertidal macroalgae are the main culprits of primary production, they release oxygen necessary for the equilibrium of the aquatic life and they present a support of fry for many species [1]. From an economic point, they present a nutritional source and a product of rising value. They are used in agriculture as fertilizer and fodder, in the food and pharmaceutical industry (agar, alginates, carrageenans are products extracted from seaweed), in textiles and in other fields [2].

The littoral zones are subjected to a strong anthropic pressure and consequently many species of algae are victims of bad adaptation. Natural or anthropogenic disturbances result in a functional and structural modification of ecosystems [3]. The decline of macroalgal communities in the Mediterranean has been reported by several authors [4-5]. In Algeria, macroalgae have been little studied [6-7]. Their exploitation is still very marginal, we found a lack of study of macroalgae in coastal waters of Ténès. Our study aims to determine the algal belts characterizing the Ténès coast, located in northern Algeria.

\section{MATERIALS AND METHODS}

\section{Sampling sites}

Our study was conducted at four coastal sites in the city of
Ténès (fig. 1). S1 (Ain El khadi), S2 (Oued El Guesseb), S3 (Maynis), S4 (Kaf Kalla) which are close to bathing beaches.

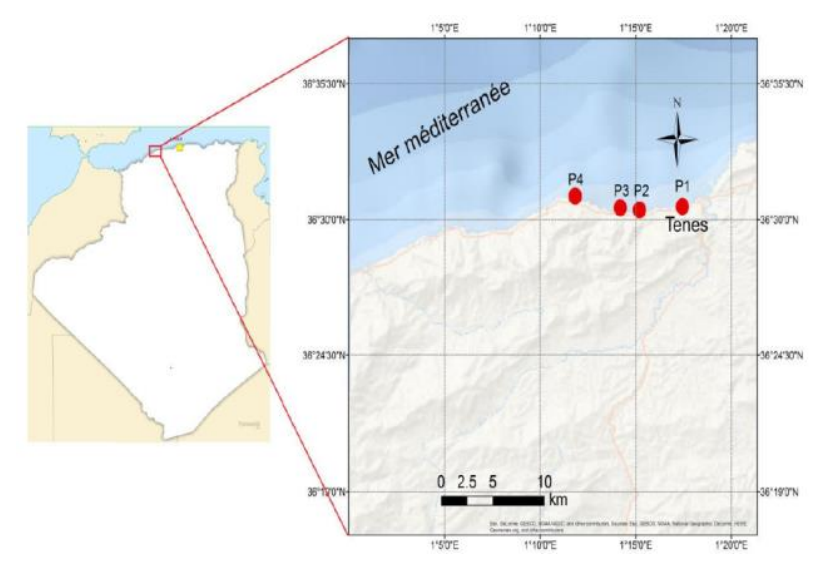

Fig. 1: Geographical location of the sampling stations on the western coast of Algeria

\section{Physicochemical analyzes of seawater}

In order to specify the sampling conditions, physicochemical parameters of the water (temperature, salinity and pH) were measured using a WTW 340 i multi parameter.

\section{Received 28 March 2018; Accepted 30 May 2018}

*Corresponding Author

Traiche Abderraouf

Département Eau, Environnement et Développement Durable, University of Chlef-Hassiba Benbouali, Algéria

Email: belhaouaribio@hotmail.fr

(CThis article is open access and licensed under the terms of the Creative Commons Attribution License (http://creativecommons.org/licenses/by/4.o/) which permits unrestricted, use, distribution and reproduction in any medium, or format for any purpose, even commercially provided the work is properly cited. Attribution - You must give appropriate credit, provide a link to the license, and indicate if changes were made. 


\section{Spatio-temporal variation of macroalgae structure Sampling}

Seasonal sampling was conducted: summer (July 2016), early autumn (October 2016), winter (January 2017), spring (April 2017). Sampling is done using a $25 \mathrm{~cm} \times 25 \mathrm{~cm}$ PVC quadrat divided into 25 squares. Each quadrat represents a survey. In total, nine surveys were conducted per site. The method adopted for our study is based on the techniques described for the study of phyto benthos [8].

\section{Species richness (SR)}

The number of species per site represents species richness (SR), one of the important aspects of biodiversity. Species are identified using an algal identification guide after observation under a binocular magnifying glass [9].

\section{Average recovery rate (ARR)}

Average recovery is the percentage of the substrate surface covered by the species [8]. The average recovery rate (ARR) is calculated according to the following equation:

$$
\mathrm{ARR}=\Sigma \mathrm{Ri} / \mathrm{N}
$$

The overlap (Ri) is the percentage of the area of the quadrat covered by species $\mathrm{i}$. $\mathrm{N}$ represents the number of readings.

\section{RESULTS AND DISCUSSION}

\section{Physicochemical parameters}

The physicochemical parameters of the seawater have been determined at the time of sampling (table 1 ).

Values of salinity of the water at the 06 sites during the four seasons are higher than 35g/l and do not exceed 40g/l. These values are characteristic of the salinity of Algerian marine waters [10]. The recorded temperature $\left(7.5^{\circ} \mathrm{C}\right.$ in winter and $22.5{ }^{\circ} \mathrm{C}$ in summer) does not indicate any thermal pollution. The ph is slightly alkaline, it varies between 8,23 and 8,51. These values are located near the average 8.2 which is favorable to development of aquatic life [11].

\section{Species richness (SR)}

The species observed at each site during the four seasons are listed in the table 2.

Diversity of macroalgae in our study area shows the presence of 05 species Pheophytes, 01 species Rhodophytes, 03 species chlorophytes. The highest number of algae was recorded in Summer and early autumn (o9 algae). Some authors claim that summer is the most favorable season of algae development [12]. In most sites the lowest specific wealth is recorded in winter. As a result, we conclude that the maximum development of algae in our study area located on the western Algerian coast, extends all summer, the mortality of algae occurs after the beginning of autumn. We note that the species we have identified have been observed previously on the Algerian coast [13]. The observed algae, especially Ulva and Cystoseira are algae of economic interest. Indeed Ulva is used in pharmacy, animal feed and as fertilizer; Cystoseira is used in the chemical industry and as a fertilizer [2-14]. On the other hand, the algae we observed can be used in the assessment of the ecological status index of coastal waters CARLIT [15-17].

\section{Average recovery of species in each season}

The average recovery of each species in the six sites during the four seasons is shown in fig. 2, 3, 4, 5 .

During the summer and automn (at the nine sites), dominance is shared by several algae including Ulva. During winter and spring, dominance is shared by Ulva and Cystoseira. Indeed, several studies have reported dominance of Ulva in degraded environments [18-19]. On the other hand, Cystosoeira are vulnerable species unable to withstand excessive disturbances of the environment [3]. They are considered sensitive to pollution and water turbidity as well as overgrazing by grazing organisms as evidenced by their regression throughout the Mediterranean [20]. A more pronounced disturbance of the biotope could give the advantage to Ulva, the most resistant algae. In addition, the Spongomorpha arcta species recorded the lowest recovery rate, less than $06 \%$, which suggests that the species has a restricted ecological niche. Our results showed that the recovery rate of each one of the o9 species within the same site varies from one season to another. The composition and distribution of communities is influenced by coastal morphology and hydrodynamics, but also by nutrient inputs and climatic conditions [21-1].

Table 1: Physicochemical parameters of the water

\begin{tabular}{|c|c|c|c|c|c|}
\hline & & S1 & S2 & S3 & S4 \\
\hline \multirow{3}{*}{ Summer } & $\mathrm{pH}$ & 8.23 & 8.24 & 8.28 & 8.25 \\
\hline & Température $\mathrm{C}^{\circ}$ & 22 & 22 & 22 & 22.5 \\
\hline & Salinity g/l & 39.27 & 38.00 & 38.52 & 38.16 \\
\hline \multirow{4}{*}{ Autumn } & $\mathrm{pH}$ & 8.37 & 8.41 & 8.41 & 8.39 \\
\hline & Température $\mathrm{C}^{\circ}$ & 18 & 18 & 19 & 20.5 \\
\hline & Salinity g/l & 39.84 & 39.75 & 38.71 & 37.26 \\
\hline & $\mathrm{pH}$ & 8.49 & 8.51 & 8.49 & 8.49 \\
\hline \multirow[t]{2}{*}{ Winter } & Température $\mathrm{C}^{\circ}$ & 7.5 & 8 & 8.5 & $7 \cdot 5$ \\
\hline & Salinity g/l & 39.92 & 38.89 & 38.45 & 39.69 \\
\hline \multirow{3}{*}{ Spring } & $\mathrm{pH}$ & 8.45 & 8.42 & 8.42 & 8.48 \\
\hline & Température $\mathrm{C}^{\circ}$ & 19 & 18 & 19.5 & 19 \\
\hline & Salinity g/l & 39.99 & 39.90 & 39.34 & 39.65 \\
\hline
\end{tabular}


Table 2: Specific wealth of the six sites

\begin{tabular}{|c|c|c|c|c|c|}
\hline Species & Sites & Summer & Automn & Winter & Spring \\
\hline \multicolumn{6}{|l|}{ Pheophytes } \\
\hline Cystoseira spp & Site 1 & + & + & - & - \\
\hline Cystoseira mediterranea & & - & - & + & + \\
\hline Cystoseira amentacea & & + & + & + & + \\
\hline Padina pavoniqua & & + & + & + & - \\
\hline Cystoseira tamariscifolia & & - & - & - & - \\
\hline Rhodophytes & & + & + & + & + \\
\hline Laurencia obtusa & & + & + & + & + \\
\hline Chlorophytes & & - & - & - & - \\
\hline Ulva lactuca & & - & - & - & - \\
\hline \multicolumn{6}{|l|}{ Ulva spp } \\
\hline \multicolumn{6}{|l|}{ Spongomorpha arcta } \\
\hline \multicolumn{6}{|l|}{$\begin{array}{l}\text { Pheophytes } \\
\text { Phentule }\end{array}$} \\
\hline Cystoseira spp & Site 2 & + & + & - & - \\
\hline Cystoseira mediterranea & & + & + & - & + \\
\hline Cystoseira amentacea & & + & + & + & + \\
\hline Padina pavoniqua & & + & + & - & - \\
\hline Cystoseira tamariscifolia & & + & + & + & + \\
\hline Rhodophytes & & + & + & - & - \\
\hline Laurencia obtusa & & + & + & + & + \\
\hline Chlorophytes & & + & + & + & + \\
\hline Ulva lactuca & & + & + & + & - \\
\hline \multicolumn{6}{|l|}{ Ulva spp } \\
\hline \multicolumn{6}{|l|}{ Spongomorpha arcta } \\
\hline \multicolumn{6}{|l|}{ Pheophytes } \\
\hline Cystoseira spp & Site 3 & - & - & - & - \\
\hline Cystoseira mediterranea & & - & - & + & + \\
\hline Cystoseira amentacea & & - & - & - & + \\
\hline Padina pavoniqua & & + & + & + & - \\
\hline Cystoseira tamariscifolia & & - & - & + & + \\
\hline Rhodophytes & & - & - & + & - \\
\hline Laurencia obtusa & & + & + & + & + \\
\hline Chlorophytes & & + & + & + & + \\
\hline Ulva lactuca & & - & - & - & - \\
\hline \multicolumn{6}{|l|}{ Ulva spp } \\
\hline \multicolumn{6}{|l|}{ Spongomorpha arcta } \\
\hline \multicolumn{6}{|l|}{ Pheophytes } \\
\hline Cystoseira spp & Site 4 & + & + & - & - \\
\hline Cystoseira mediterranea & & - & - & - & + \\
\hline Cystoseira amentacea & & - & - & - & + \\
\hline Padina pavoniqua & & + & + & + & - \\
\hline Cystoseira tamariscifolia & & - & - & - & + \\
\hline Rhodophytes & & - & - & - & - \\
\hline Laurencia obtusa & & + & + & + & + \\
\hline Chlorophytes & & + & + & - & - \\
\hline Ulva lactuca & & - & - & - & - \\
\hline \multicolumn{6}{|l|}{ Ulva spp } \\
\hline Spongomorpha arcta & & & & & \\
\hline
\end{tabular}


Traiche Abderraouf et al.

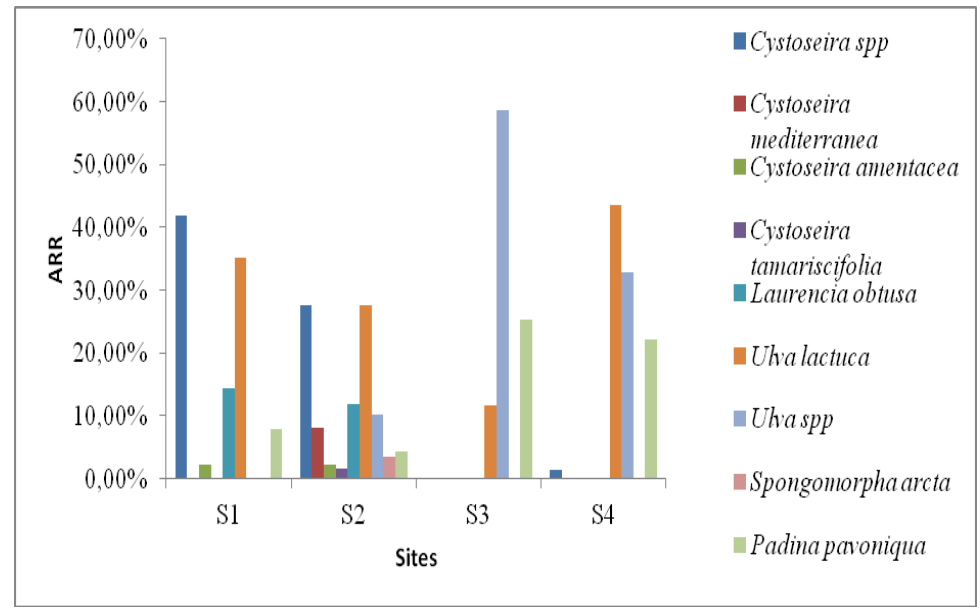

Fig. 2: Average recovery of species in summer

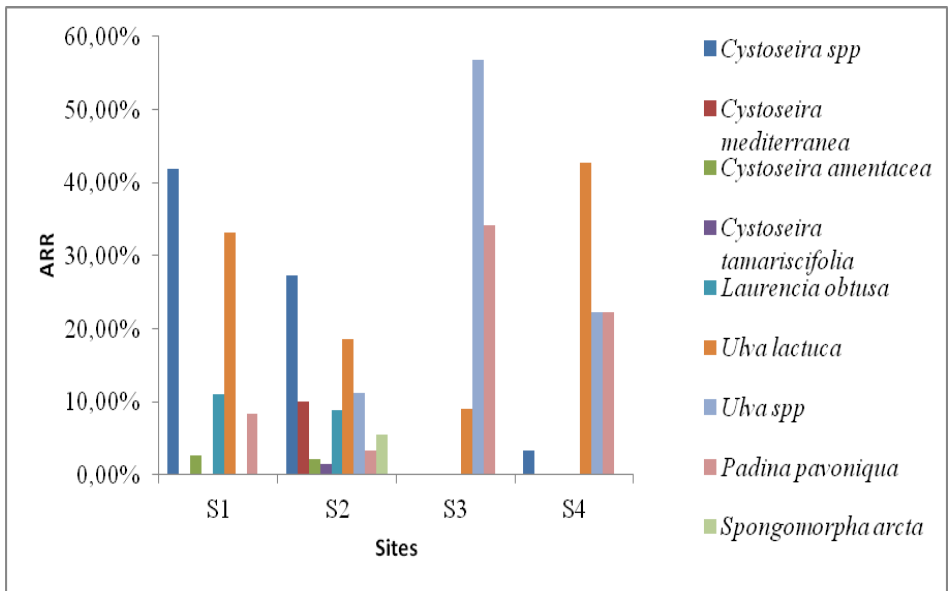

Fig. 3: Average recovery of species in autumn

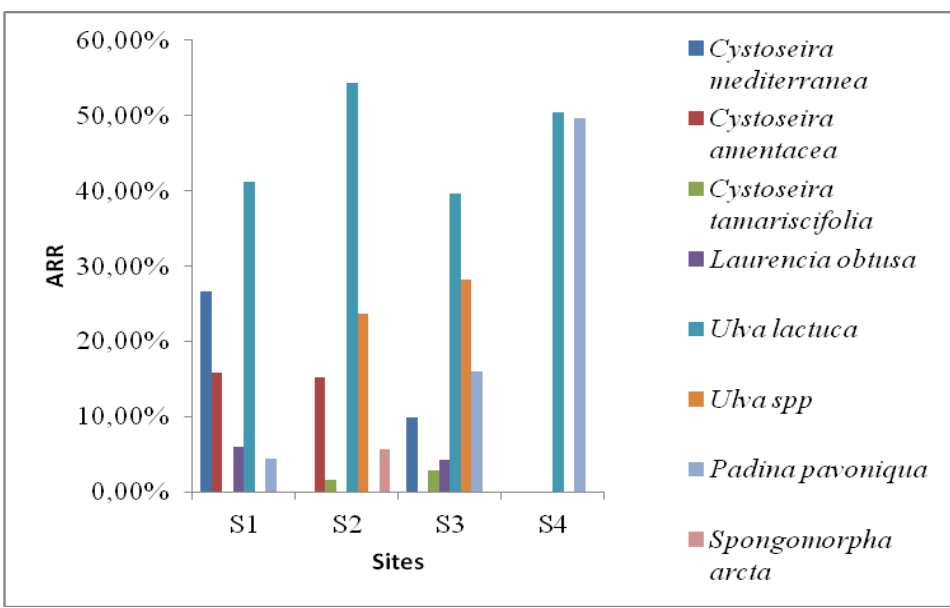

Fig. 4: Average recovery of species in winter 


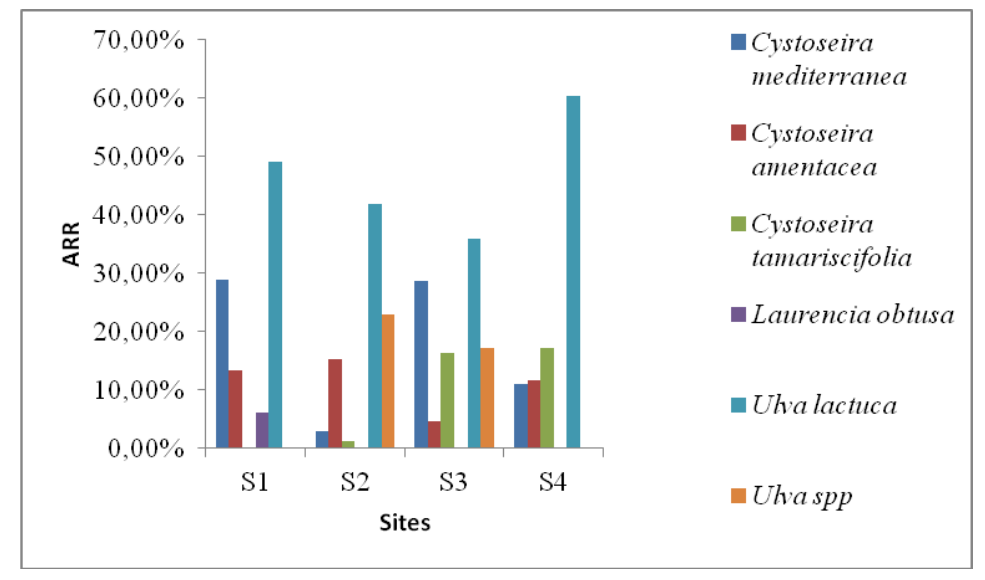

Fig. 5: Average recovery of species in spring

\section{CONCLUSION}

Our study allowed to a very important component of marine biodiversity. The macroalgae of the Algerian coast remain little studied. Assessment of species richness has revealed that the number of species of the coast of Ténès increases during the summer and early autumn. We found that the variation in the average recovery rate of species during the four seasons does not obey a specific rule, as it remains influenced by several biotic and abiotic factors. This study is worth pursuing in other areas of the Algerian coast to better understand of the evolution of intertidal macroalgae. The assessment of the CARLIT ecological index is recommended in the future.

\section{REFERENCES}

1. L Pereira, J. M Neto. Biodiversity, Taxonomy, Environmental Assessment, and Biotechnology. Taylor and Francis, 2015.

2. L Barsanti, P Gualtier. Algae: Anatomy, Biochemistry, and Biotechnology CRC Press, 2014.

3. [3. T Thibaut, A Blanfuné. Evaluation écologique du littoral rocheux de l'Air Marine Protégée de Karaburun-Sazani. Intiative PIM, 2014.

4. T Thibaut, S Pinedo, X Torras, E Ballesteros. Long-term decline of the populations of Fucales (Cystoseira, Sargassum) in the Albères coast north western (Mediterranean). Marine Pollution Bulletin. 2005. 50, 1472-1489.

5. D Serio, G Alongi, M Catra, M Cormaci, G Furnari. Changes in the benthic algal flora of Linosa Island (Strait of Sicily, Mediterranean Sea). Bot. Mar. 2006, 49, 135-144.

6. E Laib, E Leghouchi. $\mathrm{Cd}, \mathrm{Cr}, \mathrm{Cu}, \mathrm{Pb}$, and $\mathrm{Zn}$ concentrations in Ulva lactuca, Codium fragile, Jania rubens, and Dictyota dichotoma from Rabta Bay, Jijel (Algeria). Environ Monit Assess. 2012, 184, 1711-1718.

7. N Ould-Ahmed, A Gómez Garreta, M Antonia Ribera Siguan, N Bouguedoura. Checklist of the benthic marine macroalgae from Algeria. Anales del Jardín Botánico de Madrid. 2013, 70, 136-143.

8. C. F Boudouresque. Methodes d'étude qualitative et quantitative du benthos. TETHYS. 1971, 3, 79-104.

9. J Cabioc'h, J. Y Floc'h, A Le Toquin, C. F Boudouresque. Algues des mers d'Europe. Delachaux et Niestlé, 2014.

10. Z. Boutiba. Cetaceans in Algerian coastal waters. European Research. 1994. 8, 104-105.

11. M Marchand. L'océan sous haute surveillance. Quae, 2013.
12. M Menendez, F. A Comin. Spring and Summer Proliferation of Floating Macroalgae in a Mediterranean Coastal Lagoon (Tancada Lagoon, Ebro Delta, NE Spain). Estuarine Coastal and Shelf Science. 2000, 51, 215-226.

13. M Perrete-Boudouresque, H Seridi. Inventaire des algues marines benthiques d'Algérie. GIS Posidonie, 1989.

14. D B Stengel, S. Connan and Z. A. Popper. Algal chemodiversity and bioactivity: sources of natural variability and implications for commercial application. Biotechnology Advances. 2011. 29, 483-501.

15. R Arevalo, S Pinedo, E Ballesteros. Changes in the composition and structure of Mediterranean rockyshore communities following a gradient of nutrient enrichment: descriptive study and test of proposed methods to assess water quality regarding macroalgae. Marine Pollution Bulletin. 2007, 104-113.

16. E Ballesteros, $\mathrm{X}$ Torras, $\mathrm{S}$ Pinedo, $\mathrm{M}$ Garcia, L Mangialajo, M Torres. A new methodology based on littoral community cartography dominated by macroalgae for the implementation of the European Water Framework Directive. Marine Pollution Bulletin. 2007, 55, 172-180.

17. M Cavallo, X Torras, O Mascaró, E Ballesteros. Effect of temporal and spatial variability on the classification of the Ecological Quality Status using the CARLIT Index. Marine Pollution Bulletin. 2016. 102, 122-127.

18. X Guinda, J. A Juanes, A Puente, J. A Revilla. Comparison of two methods for quality assessment of macroalgae assemblages, under different pollution types. Ecological Indicators. 2008. 8, 749-753.

19. G Apaydını, V Aylikci, E Cengiz, M Saydam, N Küp, E Tirasoglu. Analysis of Metal Contents of Seaweed (Ulva lactuca) from Istanbul, Turkey by EDXRF. Turkish Journal of Fisheries and Aquatic Sciences. 2009, 10, 215-220.

20. C. F Boudouresque, E Ballesteros, N Ben maiz, F Boisset, E Bouladier, F Cinelli, S Cirik, M Cormaci, A Jeudy De Grissac, J Laborel, E Lanfranco, B Lundberg, H Mayhoub, A Meinesz, P Panayotidis, R Semroud, J. M Sinnassamy, A Span, G Vuignier. Livre rouge des végétaux, peuplements et paysages marins menacés de Méditerranée. PNUE, 1990.

21. J Birje, M Verlaque, F Poydenot. Macrophytobenthos des platiers rocheux intertidaux et semi-exposés de la région de Safi-Essaouira (Maroc occidental). Oceanologica Acta. 1996. 19 , 561-574. 